\section{Blockchain in accounting research: current trends and emerging topics}

Blockchain in accounting research

Tatiana Garanina and Mikko Ranta

School of Accounting and Finance, University of Vaasa, Vaasa, Finland, and John Dumay

Department of Accounting and Corporate Governance, Macquarie University, Sydney, Australia;

Nyenrode Business Universiteit, Breukelen, The Netherlands and Aalborg University Business School, Aalborg Universitet, Aalborg, Denmark

\begin{abstract}
Purpose - This paper provides a structured literature review of blockchain in accounting. The authors identify current trends, analyse and critique the key topics of research and discuss the future of this nascent field of inquiry.

Design/methodology/approach - This study's analysis combined a structured literature review with citation analysis, topic modelling using a machine learning approach and a manual review of selected articles. The corpus comprised 153 academic papers from two ranked journal lists, the Association of Business Schools (ABS) and the Australian Business Deans Council (ABDC), and from the Social Science Research Network (SSRN). From this, the authors analysed and critiqued the current and future research trends in the four most predominant topics of research in blockchain for accounting.

Findings - Blockchain is not yet a mainstream accounting topic, and most of the current literature is normative. The four most commonly discussed areas of blockchain include the changing role of accountants; new challenges for auditors; opportunities and challenges of blockchain technology application; and the regulation of cryptoassets. While blockchain will likely be disruptive to accounting and auditing, there will still be a need for these roles. With the sheer volume of information that blockchain records, both professions may shift out of the back-office toward higher-profile advisory roles where accountants try to align competitive intelligence with business strategy, and auditors are called on ex ante to verify transactions and even whole ecosystems.

Research limitations/implications - The authors identify several challenges that will need to be examined in future research. Challenges include skilling up for a new paradigm, the logistical issues associated with managing and monitoring multiple parties all contributing to various public and private blockchains, and the pressing need for legal frameworks to regulate cryptoassets.

Practical implications - The possibilities that blockchain brings to information disclosure, fraud detection and overcoming the threat of shadow dealings in developing countries all contribute to the importance of further investigation into blockchain in accounting.

Originality/value - The authors' structured literature review uniquely identifies critical research topics for developing future research directions related to blockchain in accounting.
\end{abstract}

Keywords Blockchain, Accounting, Literature review, Machine-learning approach, Future trends

Paper type Literature review

\section{Introduction}

Blockchain is a technology for storing and verifying transactional records that works by adding "blocks" of data to a ledger, called the blockchain, that is maintained across a network of peer-to-peer computers (Coyne and McMickle, 2017). It is a potentially disruptive technology that has begun to have dramatic impacts on the business models and market

(C) Tatiana Garanina, Mikko Ranta and John Dumay. Published by Emerald Publishing Limited. This article is published under the Creative Commons Attribution (CC BY 4.0) licence. Anyone may reproduce, distribute, translate and create derivative works of this article (for both commercial and noncommercial purposes), subject to full attribution to the original publication and authors. The full terms of this licence may be seen at http://creativecommons.org/licences/by/4.0/legalcode
Received 29 October 2020 Revised 3 June 2021 17 August 2021

Accepted 13 September 2021 
AAAJ 35,7

1508 structures of many industries (Casey and Vigna, 2018), including accounting (Bonsón and Bednárová, 2019; Deloitte, 2016). However, the wealth of information produced about blockchain can make it challenging for researchers to stay up-to-date with the latest developments (Cai et al., 2019; Linnenluecke et al., 2020). In these circumstances, the role of a structured literature review (SLR) of emerging research of blockchain in accounting should be a helpful tool (Cai et al., 2019; Moro et al., 2015).

There are published literature reviews on how blockchain might be applied in a wide variety of academic disciplines, including business and management (Xu et al., 2019), supply chains (Wang et al., 2019; Gurtu and Johny, 2019), FinTech (Cai, 2018; Rabbani et al., 2020), the Internet of things (Conoscenti et al., 2016), and even cities (Shen and Pena-Mora, 2018) but there has only been one for accounting and it was limited to 16 articles and 20 industry reports/websites (Schmitz and Leoni, 2019). Other authors have also proposed different ways of applying blockchain technology in accounting and auditing (e.g. Yu et al., 2018; Kokina et al., 2017; Faccia and Mosteanu, 2019; Bonsón and Bednárová, 2019), without offering a comprehensive overview. Similarly, Bonsón and Bednárová (2019, p. 737) conclude that "blockchain is an under-explored phenomenon, [and] future research is necessary to obtain a full understanding of this emerging technology and its implications for the accounting and auditing sphere".

Considering the under-explored impact of blockchain in accounting and the changes blockchain technology could have on accounting practice, it is timely to see how academic research is evolving. Hence, following the SLR methodology (Massaro et al., 2016), this review will answer three research questions:

$R Q 1$. What are the current major research trends and topics related to blockchain for accounting?

$R Q 2$. What is the focus and critique of the key research topics?

RQ3. What are the future research trends related to blockchain in accounting?

The studies collected for the review were drawn from accounting journals indexed by the Association of Business Schools (ABS), the Australian Business Deans Council (ABDC) and the Social Science Research Network (SSRN). To help analyse the corpus, we enlist the support of machine learning as found in other studies (Cai et al., 2019; El-Haj et al., 2019; Black et al., 2020; Bentley et al., 2018). From this, we contribute and provide a comprehensive picture and critique of the literature on blockchain in accounting. This includes an analysis of impact; an examination of the four most widely-examined topics, being the changing role of accountants, new challenges for auditors, the opportunities and challenges of blockchain technology application and the regulation of cryptoassets; and a discussion on areas for future research. Identifying emerging topics in the field is an important element in generating insights for future research (Small et al., 2014) and leading research innovations (Cozzens et al., 2010). Understanding what we have learnt and how blockchain technology is impacting accounting is of benefit to everyone connected to this area. It may also help to guide future research in this exciting area.

The remainder of the paper is as follows. In Section 2, we discuss the concept of blockchain as an accounting technology. Section 3 outlines the methodology used for the review, followed by the results in Section 4. The most representative articles are analysed in Section 5, with future research directions discussed in Section 6. Section 7 concludes the paper with the implications of this research for theory, practice and policy, along with the limitations of the study.

\section{Blockchain in accounting}

There are many different implementations of blockchain, and it will likely take some time before the academic, corporate and technology communities settle on a single definitive 
version of this technology, if they ever do (Sheldon, 2019). Fanning and Centers (2016, p. 53) describe blockchain as "a distributed database that maintains a continuously growing list of data records that are hardened against tampering and revision, even by operators of the data store's nodes". Therefore, as a decentralised public ledger, blockchain might potentially serve as a secure accounting information system. Moll and Yigitbasioglu (2019, p. 7) explain:

The main advantage of blockchain technology is that once a transaction is approved by the nodes in the network, it cannot be reversed or re-sequenced. The inability to modify a transaction is essential for the blockchain's integrity and ensures that all parties have accurate and identical records. Because blockchain is a distributed system, all changes to a ledger are transparent to all the members of a network.

Hence, if transparency is key, implementing blockchain may help to enhance a company's competitive advantage (Deloitte, 2019), and it should certainly help to cultivate trust between market participants (Yu et al., 2018). In blockchain, the transaction verification process is not managed centrally. Rather, it involves all the computers in the network, so blockchain does not suffer from point of failure events. Nor can individuals collude to override controls or illicitly change or delete official accounting records (Wang and Kogan, 2018). Companies that incorporate blockchain into their accounting systems therefore may reduce their risk of fraud (Dai et al., 2017). Using blockchain might also mean more transactions can be automated, less data are lost, transactions can be tracked better and users' needs throughout the process can be detected more easily (Fullana and Ruiz, 2021; Bonsón and Bednárová, 2019). However, the primary and most valuable difference between traditional databases and blockchain is its novel solution to control whereby transactions cannot be deleted or changed (Coyne and McMickle, 2017; Dai et al., 2017).

Even though, for most industries, blockchain is still a new and not yet well-established technology, the World Economic Forum estimates that, by 2025, at least $10 \%$ of global gross domestic product (GDP) will rely on blockchains. And, by 2030, blockchains will have created $\$ 3.1 \mathrm{tn}$ in business value (Panetta, 2018). It should therefore be unsurprising to consider that this revolution will start to change the nature of accounting and, in turn, the work of its practitioners and theorists (e.g. Yermack, 2017; Schmitz and Leoni, 2019; Yu et al., 2018).

As such, a literature review on the status of blockchain in accounting is both topical and timely. The insights provided into this emerging technology will have implications for the accounting ecosystem-some beneficial, others challenging. Hopefully, this SLR will serve as a helpful baseline for practitioners, professionals and academics as we navigate the next potential revolution in accounting information systems.

\section{Methodology}

Massaro et al. (2016, p. 2) characterise an SLR as "a method for studying a corpus of scholarly literature, to develop insights, critical reflections, future research paths and research questions". The review process is conducted in several steps.

\subsection{The research questions}

The first step is to develop the research questions by following a standard template that takes the researcher from developing insights, critiquing the results and providing a way forward through transformative redefinitions (Alvesson and Deetz, 2000). As noted in the Introduction, our three questions are:

$R Q 1$. What are the major trends and topics developing within the research related to blockchain in accounting?

$R Q 2$. What is the focus and critique of the key identified research topics? 
$R Q 3$. What are the future research trends related to blockchain in accounting?

35,7

\subsection{Defining a set of articles for further analysis}

When conducting an SLR, it is important to assemble a proper body of literature so as not to bias the results (Massaro et al., 2016). We selected the research articles for this study following a three-phase procedure.

Phase 1. We first composed a list of all accounting journals from the 2018 Chartered Association of Business Schools rankings (the ABS rankings), which amounted to 87 journals. We did the same for the 2019 Australian Business Deans Council Journal Quality List (the ABDC rankings). This netted 157 journals.

Phase 2. After removing duplicate journals covered in both ranking systems, we were left with 149 journals. In these, we looked for relevant papers published in the period Jan 2008 till June of 2020. We started our search in 2008 as this was when Satoshi Nakamoto first mentioned blockchain in his paper (Nakamoto, 2008). Using the EBSCO, Scopus and Web of Science databases, we searched for any article with the key words "blockchain" or "distributed ledger technology" in the title or abstract. From 2,335 documents, we identified 112 papers that matched our criteria for publication source.

Phase 3. Massaro et al. (2016) outline that when undertaking an SLR, researchers should broaden the boundaries if there is very little published research. They also warn that what is published may already be out of date because of the long lead times involved in publishing academic articles. Massaro et al. (2016) bring clarity to "broadening the boundaries", arguing that researchers need to search for sources other than academic journals, which may provide valuable insights into emerging research fields. The other sources might include conferences and open-source publishing platforms that offer researchers greater opportunities to disseminate their research to practice (Massaro et al., 2015).

Since blockchain is just such an emerging topic in the accounting literature (Schmitz and Leoni, 2019; Bonsón and Bednárová, 2019; Yu et al., 2018), we decided to add papers not yet published in the accounting journals but uploaded to the SSRN. SSRN is the leading social science and humanities repository and online community that provides "tomorrow's research today" (Gordon, 2016). With more than 950,000 papers from over half a million authors in the e-library, SSRN offers an extensive pool of research ideas that can be tracked before publication to detect emerging research topics and current trends. These papers added an important contribution to our literature review. Here, we searched for "accounting" AND "blockchain" or "accounting AND distributed ledger" over the same period and found 68 papers, some of which overlapped with papers already retrieved. These were excluded, plus we also excluded any of the papers that had subsequently been published in a non-accounting journal or an accounting journal not ranked by ABS or ABDC. This left 41 additional articles to add to the corpus. Thus, our final sample comprised 153 papers on blockchain for accounting.

Portable Document Format (PDF) versions of each of the articles were downloaded and stored in a Mendeley database with full referencing details. The sources and number of papers from each source are given in Table 1.

\subsection{Methods of analysis: Latent Dirichlet Allocation combined with manual analysis}

In machine learning, there are many different text mining techniques, each designed to suit different types of data and different end purposes (see Wanner et al., 2014 for a comprehensive review). We used a Latent Dirichlet Allocation (LDA) model, which is well- 


\begin{tabular}{|c|c|c|c|c|c|}
\hline Source & $\begin{array}{l}\mathrm{ABS} \\
\text { ranking }\end{array}$ & $\begin{array}{l}\mathrm{ABDC} \\
\text { ranking }\end{array}$ & $\begin{array}{l}\text { Number of } \\
\text { papers }\end{array}$ & $\begin{array}{l}\% \text { of total in } \\
\text { dataset }\end{array}$ & $\begin{array}{l}\text { Blockchain in } \\
\text { accounting }\end{array}$ \\
\hline Accounting Review & $4^{*}$ & $A^{*}$ & 1 & 0.65 & \\
\hline Review of Accounting Studies & 4 & $\mathrm{~A}^{*}$ & 1 & 0.65 & \\
\hline British Accounting Review & 3 & $\mathrm{~A}^{*}$ & 2 & 1.31 & \\
\hline Abacus & 3 & $\mathrm{~A}$ & 1 & 0.65 & \\
\hline International Journal of Accounting & 3 & $\mathrm{~A}$ & 1 & 0.65 & 1511 \\
\hline Journal of Accounting and Public Policy & 3 & A & 1 & 0.65 & \\
\hline $\begin{array}{l}\text { Journal of International Accounting, Auditing and } \\
\text { Taxation }\end{array}$ & 3 & $\mathrm{~B}$ & 1 & 0.65 & \\
\hline Accounting and Finance & 2 & A & 4 & 2.61 & \\
\hline Australian Accounting Review & 2 & $\mathrm{~B}$ & 7 & 4.58 & \\
\hline Current Issues in Auditing & 2 & $\mathrm{~B}$ & 3 & 1.96 & \\
\hline $\begin{array}{l}\text { International Journal of Accounting Information } \\
\text { Systems }\end{array}$ & 2 & A & 7 & 4.58 & \\
\hline $\begin{array}{l}\text { International Journal of Disclosure and } \\
\text { Governance }\end{array}$ & 2 & $\mathrm{~B}$ & 2 & 1.31 & \\
\hline Managerial Auditing Journal & 2 & $\mathrm{~A}$ & 1 & 0.65 & \\
\hline $\begin{array}{l}\text { Sustainability Accounting, Management and } \\
\text { Policy Journal }\end{array}$ & 2 & $\mathrm{~B}$ & 1 & 0.65 & \\
\hline Accounting Education & 2 & A & 1 & 0.65 & \\
\hline $\begin{array}{l}\text { Australasian Accounting, Business and Finance } \\
\text { Journal }\end{array}$ & 1 & $\mathrm{~B}$ & 2 & 1.31 & \\
\hline $\begin{array}{l}\text { Journal of Forensic and Investigative Accounting } \\
\text { (previously Journal of Forensic Accounting) }\end{array}$ & 1 & $\mathrm{~B}$ & 1 & 0.65 & \\
\hline Management Accounting Quarterly & 1 & $\mathrm{C}$ & 2 & 1.31 & \\
\hline Meditari Accountancy Research & 1 & A & 6 & 3.92 & \\
\hline Pacific Accounting Review & 1 & $\mathrm{~B}$ & 1 & 0.65 & \\
\hline Social and Environmental Accountability Journal & 1 & $\mathrm{~B}$ & 1 & 0.65 & \\
\hline The EDP Audit, Control, and Security Newsletter & 1 & $\mathrm{C}$ & 4 & 2.61 & \\
\hline $\begin{array}{l}\text { Intelligent Systems in Accounting, Finance and } \\
\text { Management: An International Journal }\end{array}$ & 1 & $\mathrm{~B}$ & 5 & 3.27 & \\
\hline Journal of Emerging Technologies in Accounting & 1 & $\mathrm{~B}$ & 20 & 13.07 & \\
\hline Journal of Corporate Accounting and Finance & & $\mathrm{B}$ & 12 & 7.84 & \\
\hline Accounting Perspectives & & $\mathrm{B}$ & 7 & 4.58 & \\
\hline $\begin{array}{l}\text { The International Journal of Digital Accounting } \\
\text { research }\end{array}$ & & $\mathrm{B}$ & 4 & 2.61 & \\
\hline The Journal of Theoretical Accounting research & & $\mathrm{B}$ & 1 & 0.65 & \\
\hline Copernican Journal of Finance and Accounting & & $\mathrm{C}$ & 4 & 2.61 & \\
\hline $\begin{array}{l}\text { IUP Journal of Accounting research and Audit } \\
\text { Practices }\end{array}$ & & $\mathrm{C}$ & 1 & 0.65 & \\
\hline Journal of Commerce and Accounting research & & $\mathrm{C}$ & 1 & 0.65 & \\
\hline Academy of Accounting and Financial Studies & & $\mathrm{C}$ & 6 & 3.92 & \\
\hline $\begin{array}{l}\text { Journal } \\
\text { SSRN papers }\end{array}$ & & & 41 & 26.80 & $\begin{array}{l}\text { Table } 1 . \\
\text { distribution }\end{array}$ \\
\hline Total & & & 153 & 100.00 & of articl \\
\hline
\end{tabular}

suited to providing a systematic and non-biased method of investigating a body of literature (Cai et al., 2019; El-Haj et al., 2019; Black et al., 2020; Bentley et al., 2018; Fligstein et al., 2017). El-Haj et al. (2019, p. 266) explain that LDA leads to "wider generalizability, greater objectivity, improved replicability, enhanced statistical power, and scope for identifying 'hidden' linguistic features". Research shows LDA to be a relevant and useful tool for working with both big and small literature corpora (e.g. Li, 2010; Asmussen and Møller, 2019; El-Haj et al., 2019). Asmussen and Møller (2019, p. 16) highlight that applying LDA to even small sets 
AAAJ 35,7

of papers provides "greater reliability than competing exploratory review methods, as the code can be rerun on the same papers, which will provide identical results". For these reasons and more, the LDA method is currently one of the most commonly employed topic identification methods that does not simply rely on a static word frequency measure (Blei et al., 2003). Moreover, El-Haj et al. (2019, p. 292) recommend employing machine learning methods and high-quality manual analysis in conjunction as they "represent complementary approaches to analyzing financial discourse". We followed this advice, applying a hybrid approach that comprised LDA analysis, citation analysis and a manual review.

LDA allows us to explore latent relationships between terms and topics in a sample, identify the most representative articles for each topic and identify the trends within the topics. Using LDA helps us capture the idea of a document being composed of a (predetermined) number of topics that represent a probability distribution over a vocabulary. The number of topics is optimised using grid-search and coherence of topics (Röder et al., 2015). The model also supplies a list of articles that most strongly "belong" to each topic.

The text mining procedure is straightforward. In a Python environment (www.python.org), the articles are first converted from PDF documents into text files. The text is then converted into lower case, and all characters other than letters are removed. Next, stop words, such as the and, but, if, or, are removed, and the remaining words are lemmatised into their dictionary word. Additionally, all words other than nouns are discarded. Finally, the documents are turned into a bag-of-words format and fed into the LDA model.

The results showed that the four topics with the highest marginal distribution accounted for more than half of the overall content of the sample. To test the validity and reliability of this result, we applied several other types of analysis suggested by researchers working with literature reviews. For example, Dumay and Cai (2014) and Jones and Alam (2019) argue that citation impact factors are increasingly important because they identify the most influential articles. Highly cited articles represent a "corpus of scholarly literature" that can help "develop insights, critical reflections, future research paths and research questions" (Massaro et al., 2016, p. 767). To conduct a citation analysis, we use citation counts based on Google Scholar data, based on queries employing Harzing's Publish or Perish software as of 5 March 2021. This step also helped us validate that the papers and topics identified by the LDA analysis were among the most cited.

Although the LDA method helped us to identify past and current trends in the literature, Cai et al. (2019, p. 710) contend that "the human researcher is potentially better equipped to evaluate future trends in the literature". Hence, we also manually reviewed the 15 articles identified in the LDA analysis as the most representative of each topic. This review affirmed the results of the LDA analysis and gave us the opportunity to offer a critique and gain more insights while identifying future research directions.

\section{Results}

This section provides answers to RQ1: What are the current research trends and topics in blockchain for accounting?

Figure 1 demonstrates that the volume of articles on the topic is increasing annually. The first articles began to appear in 2015 and, by 2019, 4 articles had increased to 40 papers, with 35 already published just in the first half of 2020 .

Of the top-ranked journals-either 4-star ABS or A* ABDC-only two have each published one paper on blockchain. This is a clear indication that the phenomenon has not yet fallen into mainstream research. Given its relatively recent appearance in the literature, this is not surprising. Additionally, most of the articles that have been published are normative in approach and look at the future applications of blockchain in accounting. From this, we can assume that, in future, more cases of blockchain applications in accounting practice will be 


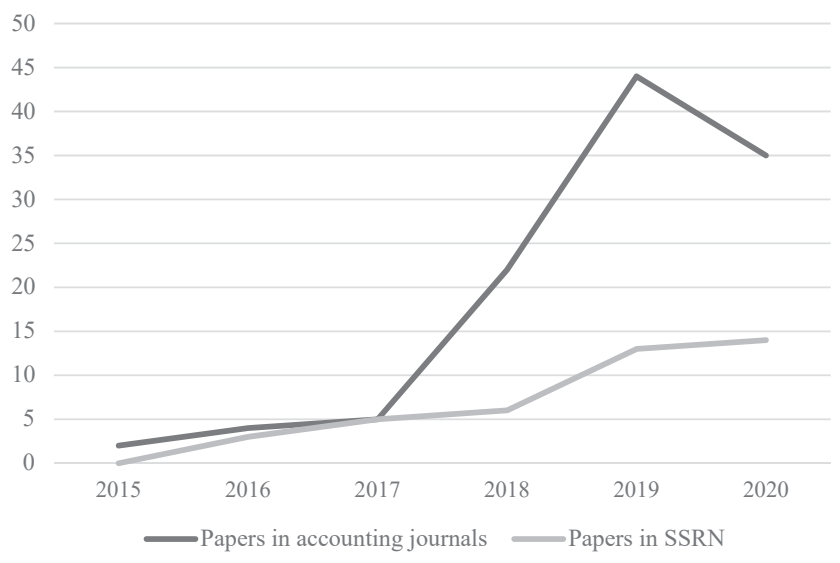

Blockchain in accounting research

1513

researched. Once the literati start to read of blockchain having a real influence on the profession, we expect the number of papers published in the leading journals will increase.

\subsection{Results of LDA analysis}

The LDA analysis unearthed ten topics, which we needed to find appropriate names for. This we did in a two-step procedure. First, we looked at the terms listed against each topic, then we read the most representative articles for each group identified by the model. One author then developed a descriptive title, which was reviewed and perhaps modified before being approved by the remaining authors. The final topic names are listed in Table 2 , along with the 20 most important words for each topic and the marginal distribution of each topic.

As shown in Table 2, the most widely analysed topics are: the changing role of accountants; new challenges for auditors; the opportunities and challenges of applying blockchain technology and the regulation of cryptoassets. These account for more than half of the papers. No other topic amounts to more than $10 \%$ of papers on its own. Figure 2 shows the representation of the different topics from 2016 to 2020 . Since there were so few papers in 2015, we did not include this year in the chart.

Two of the most widely discussed topics-"the changing role of accountants" and "the new challenges for auditors"-only seem to be getting more popular. These two subjects account for the highest proportion of the articles. Although "new skills for teams" began to attract attention in 2019, papers on this topic still only account for a small portion of the sample. Interesting, even over such a short period, interest in some topics is already waning, e.g. "FinTech in banking", "cryptocurrencies and cryptoassets", and "blockchain and taxation". With this in mind, and given the overwhelming interest in just a handful of topics, we focused the rest of our analysis on the top four topics.

\subsection{Article impact}

As mentioned in the methodology, we checked the validity and reliability of the topic results using citation analysis (Dumay et al., 2018). Table 3 shows the total citation counts for the top 10 articles as listed in Google Scholar citations (5 March 2021).

As shown, all but one of the ten most-cited articles were published in ranked accounting journals. In fact, three were published in the Journal of Emerging Technologies in Accounting. The one exception was found on SSRN. Additionally, the topics cited match the topics 

distribution

\section{4}

The new challenges for auditors

Opportunities and challenges of blockchain technology application

Regulation of cryptoassets

Cryptocurrencies and cryptoassets

Trading and uncertainty associated with blockchain and cryptocurrency

FinTech in banking

New skills for teams

Ecosystems and supply chain

Blockchain and taxation

Table 2.

List of topics
Organisation, accountant, literature, practise, role,

governance, competency, decision, innovation, area, performance, knowledge, idea, profession, perspective, impact, industry, opportunity, theory, factor

Audit, auditor, auditing, contract, procedure, client, assurance, statement, evidence, analytic, privacy, ecosystem, tool, profession, customer, volume, environment, adoption, firm, practice Block, ledger, peer, database, record, contract, design, node, entry, chain, access, function, solution, participant, problem, proof, hash, key, organisation, consensus

Token, security, issuer, investor, ico, law, directive, regulation, project, right, capital, voucher, sale, regulator, issuance, holder, protection, consumer, rule, equity

Asset, currency, bitcoin, exchange, price, cryptocurrency, carbon, investment, coin, purpose, regulation, entity, trading, amount, money, statement, money_laundering, payment, income, sale

Volume, trading, investor, disclosure, return, firm, day, percent, measure, policy_uncertainty, news, readability, product, cryptocurrency, table, car, authority_news, evidence, word, stock Payment, bank, money, account, currency, cash, consumer, claim, banking, government, btc, choice, infrastructure, customer, state, sector, platform, intermediary, transfer, member Analyst, team, forecast, member, diversity, effect, 0.24 0.16 variable, accuracy, firm, experience, performance, sample, copy, size, column, table, panel, filing, industry, teamwork

Supplier, supply_chain, buyer, traceability, access, certification, product, deforestation, food, premium, production, rent, contract, effort, sustainability, chain, standard, problem, decision, strategy

Tax, taxation, wealth, vat, detection, topic, sale, table, invoice, taxis, rule, judgement, jurisdiction, revenue, good, entity, taxpayer, crime, treatment, authority

revealed by the LDA analysis, particularly new challenges for auditors, opportunities and challenges of blockchain applications, and the regulation of cryptoassets.

Dumay and Cai (2014, p. 270) note that "One problem with determining the impact from citations alone is that older articles can accumulate more citations". To overcome this problem and to identify emerging articles, in Table 4, we also calculated the citations per year (CPY). Six articles are common to both rankings: Kim and Laskowski (2018), Fanning and Centers (2016), O'Leary (2017), La Torre et al. (2018), Kokina et al. (2017), Issa et al. (2016). This offers clear support for the results of the LDA analysis. Further, two of the articles were 


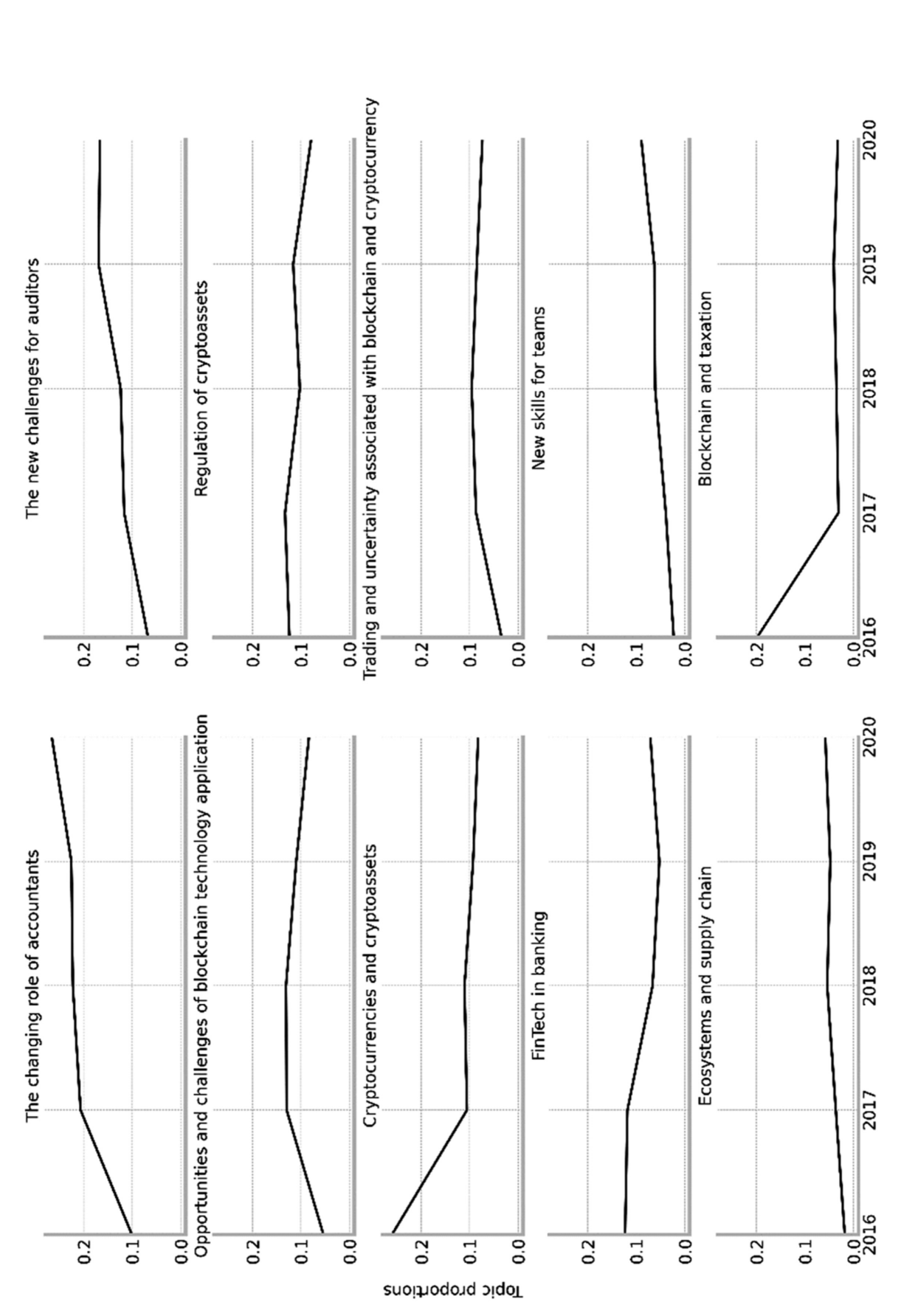

Blockchain in accounting research

1515

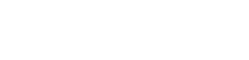


AAAJ 35,7

\begin{tabular}{ll} 
Authors, year & Title \\
\hline Kim and & $\begin{array}{l}\text { Toward an ontology-driven } \\
\text { Laskowski } \\
\text { (2018) }\end{array}$ \\
chain provenance
\end{tabular}

Fanning and

Centers (2016)

Blockchain and its coming

impact on financial services

$\begin{array}{llrl}\text { O'Leary } & \text { Configuring blockchain } & 132 & \begin{array}{l}\text { Intelligent Systems in } \\ \text { Accounting, Finance } \\ \text { and } 2017)\end{array} \\ \text { information in blockchain } & & \text { and Mangement }\end{array}$

Issa et al.

(2016)

Kokina et al.

(2017)

Coyne and

McMickle

(2017)

La Torre et al.

(2018)

Chohan (2017) consortiums: The case of accounting and supply chain systems

Research ideas for artificial intelligence in auditing: The formalisation of audit and workforce supplementation Blockchain: Emergent industry adoption and implications for accounting

Can blockchains serve an accounting purpose?

Harmonising non-financial reporting regulation in Europe

The double spending problem and cryptocurrencies

Wang and Kogan (2018)

Designing confidentialitypreserving Blockchain-based transaction processing systems

Cai (2018)

Table 3.

Disruption of financial intermediation by FinTech: a Review on crowdfunding and blockchain

71 International Journal Finance
LDA topic the paper reflects

422 Intelligent Systems in Accounting, Finance and Management

Opportunities and challenges of blockchain technology application

302 Journal of Corporate Accounting and Finance

Opportunities and challenges of blockchain technology application Opportunities and challenges of blockchain technology application

131 Journal of Emerging Technologies in Accounting

112 Journal of Emerging Technologies in Accounting

93 Journal of Emerging Technologies in Accounting

91 Meditari Accountancy

Research

72 SSRN of Accounting Information Systems

$71 \quad$ Accounting and
The new challenges for auditors

Opportunities and challenges of

blockchain technology application

Opportunities and challenges of

blockchain technology application

The new challenges for auditors

Opportunities and challenges of blockchain technology application

Opportunities and challenges of blockchain technology application Regulation of cryptoassets

published in 2019 and are already in the top 10, which is a sign of just how strong the interest in blockchain technology is.

The results of Table 4 allow us to confirm our choice of the topics for further analysis. The top 10 papers with the highest citations per year belong to one of the four research topics that have the marginal distribution over $10 \%$ represented in Table 2 and account for more than a half of the overall distribution.

\section{Key research topics: focus and critique}

In this section, we answer RQ2: What is the focus and critique of the key identified research topics? 


\begin{tabular}{|c|c|c|c|c|c|}
\hline Authors, year & Title & $\mathrm{CPY}$ & Source & $\begin{array}{l}\text { LDA topic the paper } \\
\text { reflects }\end{array}$ & accounting \\
\hline $\begin{array}{l}\text { Kim and } \\
\text { Laskowski } \\
\text { (2018) }\end{array}$ & $\begin{array}{l}\text { Toward an ontology-driven } \\
\text { blockchain design for supply- } \\
\text { chain provenance }\end{array}$ & 140.67 & $\begin{array}{l}\text { Intelligent Systems in } \\
\text { Accounting, Finance } \\
\text { and Management }\end{array}$ & $\begin{array}{l}\text { Opportunities and } \\
\text { challenges of } \\
\text { blockchain technology } \\
\text { application }\end{array}$ & \\
\hline Fanning and & Blockchain and its coming & 60.4 & Journal of Corporate & Opportunities and & 1517 \\
\hline Centers (2016) & impact on financial services & & $\begin{array}{l}\text { Accounting and } \\
\text { Finance }\end{array}$ & $\begin{array}{l}\text { challenges of } \\
\text { blockchain technology } \\
\text { application }\end{array}$ & \\
\hline O’Leary (2017) & $\begin{array}{l}\text { Configuring blockchain } \\
\text { architectures for transaction } \\
\text { information in blockchain } \\
\text { consortiums: The case of } \\
\text { accounting and supply chain } \\
\text { systems }\end{array}$ & 33 & $\begin{array}{l}\text { Intelligent Systems in } \\
\text { Accounting, Finance } \\
\text { and Management }\end{array}$ & $\begin{array}{l}\text { Opportunities and } \\
\text { challenges of } \\
\text { blockchain technology } \\
\text { application }\end{array}$ & \\
\hline $\begin{array}{l}\text { Moll and } \\
\text { Yigitbasioglu } \\
\text { (2019) }\end{array}$ & $\begin{array}{l}\text { The role of internet-related } \\
\text { technologies in shaping the } \\
\text { work of accountants: New } \\
\text { directions for accounting } \\
\text { research }\end{array}$ & 32.5 & $\begin{array}{l}\text { The British } \\
\text { Accounting Review }\end{array}$ & $\begin{array}{l}\text { The changing role of } \\
\text { accountants }\end{array}$ & \\
\hline $\begin{array}{l}\text { La Torre } \text { et al. } \\
(2018)\end{array}$ & $\begin{array}{l}\text { Harmonising non-financial } \\
\text { reporting regulation in Europe }\end{array}$ & 30.33 & $\begin{array}{l}\text { Meditari } \\
\text { Accountancy } \\
\text { Research }\end{array}$ & $\begin{array}{l}\text { The new challenges } \\
\text { for auditors }\end{array}$ & \\
\hline $\begin{array}{l}\text { Kokina et al. } \\
\text { (2017) }\end{array}$ & $\begin{array}{l}\text { Blockchain: Emergent } \\
\text { industry adoption and } \\
\text { implications for accounting }\end{array}$ & 28 & $\begin{array}{l}\text { Journal of Emerging } \\
\text { Technologies in } \\
\text { Accounting }\end{array}$ & $\begin{array}{l}\text { Opportunities and } \\
\text { challenges of } \\
\text { blockchain technology } \\
\text { application }\end{array}$ & \\
\hline $\begin{array}{l}\text { Schmitz and } \\
\text { Leoni (2019) }\end{array}$ & $\begin{array}{l}\text { Accounting and Auditing at } \\
\text { the Time of Blockchain } \\
\text { Technology: A research } \\
\text { Agenda }\end{array}$ & 28 & $\begin{array}{l}\text { Australian } \\
\text { Accounting Review }\end{array}$ & $\begin{array}{l}\text { The new challenges } \\
\text { for auditors }\end{array}$ & \\
\hline Kwilinski (2019) & $\begin{array}{l}\text { Implementation of blockchain } \\
\text { technology in accounting } \\
\text { sphere }\end{array}$ & 26.5 & $\begin{array}{l}\text { Academy of } \\
\text { Accounting and } \\
\text { Financial Studies } \\
\text { Journal }\end{array}$ & $\begin{array}{l}\text { The new challenges } \\
\text { for auditors }\end{array}$ & \\
\hline Issa et al. (2016) & $\begin{array}{l}\text { Research ideas for artificial } \\
\text { intelligence in auditing: The } \\
\text { formalisation of audit and } \\
\text { workforce supplementation }\end{array}$ & 26.2 & $\begin{array}{l}\text { Journal of Emerging } \\
\text { Technologies in } \\
\text { Accounting }\end{array}$ & $\begin{array}{l}\text { The new challenges } \\
\text { for auditors }\end{array}$ & \\
\hline $\begin{array}{l}\text { Rozario and } \\
\text { Vasarhelyi } \\
\text { (2018) }\end{array}$ & Auditing with smart contracts & 24 & $\begin{array}{l}\text { International } \\
\text { Journal of Digital } \\
\text { Accounting } \\
\text { Research }\end{array}$ & $\begin{array}{l}\text { The new challenges } \\
\text { for auditors }\end{array}$ & $\begin{array}{r}\text { Table } 4 . \\
\text { The top } 10 \text { articles } \\
\text { by CPY }\end{array}$ \\
\hline
\end{tabular}

While the LDA analysis revealed ten topics, much of the literature is focussed on four of these: the changing role of accountants, new challenges for auditors, opportunities and challenges of blockchain technology application and the regulation of cryptoassets. In the next sections, we analyse and critique these subject areas in more detail, paying attention to the papers that the model deemed to be strongly representative of each topic.

\subsection{The changing role of accountants}

Each of the papers on this topic discusses ideas about how the role of accountants and accounting treatments would change if/when blockchain becomes a mainstream technology. 
AAAJ 35,7

For example, several authors discuss the advantages of using blockchain to record transactions on a real-time basis (Yermack, 2017; Dai and Vasarhelyi, 2017). Routine accounting data would be recorded permanently with a timestamp, preventing it from being altered ex-post, which Alles (2018) argues would further ensure the reliability of current accounting information systems. Real-time accounting would also reduce the potential opportunities for earnings management (Yermack, 2017). Additionally, using blockchain means anyone can review all transactions, even those that may be suspicious or related to conflicts of interest. Irreversible transactions also mean accountants could not backdate sales or report depreciation expenses in future periods when they should be expensed immediately. As a tool for accuracy and transparency, blockchain places pressure on accountants to justify their accounting choices. It also creates a closer link between accounting and a company's responsibilities to its stakeholders and makes it more challenging for financially-distressed companies to hide their situation (Smith, 2017).

Blockchain would also change the data recognition process from double-entry accounting to a triple-entry system where every transaction leads to three entries: recording the debit, recording the credit and the cryptographic signature verifying a transaction's validity (Moll and Yigitbasioglu, 2019). In this system, blockchain is a neutral intermediary responsible for distributing the data, automating storage and verifying the process. Moreover, it would serve as a secure platform for accounting that does not allow for tampering or irregular accounting practices. The blockchain would record both monetary exchanges between two parties, such as bill payments and bank deposits, and the money flows internal to a company. Thus, the role of accountants might change into one of verifying ledger transactions (Dai and Vasarhelyi, 2017). Yermack (2017, p. 24) extrapolates on this idea, raising conjectures over some of the changes that might result should this come to pass. One of these is the idea that accountants may no longer be required to perform one of their most key functions-preparing financial statements:

Anyone could aggregate the firm's transactions into the form of an income statement and balance sheet at any time, and they would no longer need to rely on quarterly financial statements prepared by the firm.

We agree that blockchain will impact how accounting information is recorded, but we do not expect that accounting functions will disappear. Rather, accountants will likely retain some old functions, either as-is or modified to suit the new paradigm, and find they have an entirely new set of responsibilities, some of which will require them to develop new skills. For example, well-developed IT competencies may become a prerequisite for the accounting profession, at least in the interim period where firms are prepared to face the changes brought about by integrating blockchain (Uwizeyemungu et al., 2020; McGuigan and Ghio, 2019). That said, we do not think that such changes will happen overnight. It will take time before companies implement blockchain as a 'foundational technology', and any disruptions to the profession will take place over years (Iansiti and Lakhani, 2017, p. 4).

What could be an even more profound transformation of the profession is how the work of accountants might no longer involve only recording transactions. In future, accountants may need to provide professional judgements during the accounting process (McGuigan and Ghio, 2019; Dai and Vasarhelyi, 2017). Even if blockchain takes over the recording and storing of basic accounting transactions, there will be a need to decide on the choice of the most appropriate amortisation and depreciation methods, the length of the useful life of property, plant and equipment, the accounting policies regarding accounting for inventories and fairvalue accounting. Moreover, with an increase in the number of cryptoassets and initial coin offerings (ICOs) accountants may also need to develop their skills as advisors and consultants on how to report these kinds of assets and transactions. Further, if blockchain is implemented on a broad scale, accountants will not only have more information for planning and control, 
they may be required to synthesise it. This, too, will change the role of accountants, particularly management accountants. No longer relegated to the back office, accountants would likely take a much more prominent position as agents of intelligence, advising, communicating and attempting to closely link their firm's activities to strategic decisionmaking.

Blockchain may also lead to more disclosures of non-financial information, such as that related to sustainability and corporate social responsibility. The transparency of blockchain might prompt companies to do more explaining. They may wish to quantify and make visible "feel-good" information as a counterpart to the financial (Smith, 2017). Additionally, blockchain provides opportunities to collect qualitative social and environmental data, which will continue to require assurance in the future. La Torre et al. (2018) argue that blockchain will generate an automatic assurance system for non-financial information that could substantially modify the current assurance paradigm. Therefore, blockchain may help accountants move away "from traditional accounting assumptions, such as monetary unit[s], economic entit[ies] and time periods, leading organisations more towards holistic views of their relations with the society" (McGuigan and Ghio, 2019, p. 800).

Lev and $\mathrm{Gu}(2016)$ argue that blockchain may reduce information asymmetry and lead to more effective decision-making. They put forward that the relevance of information disclosed only in financial statements is diminishing because of the growing importance of non-financial information and that blockchain's ability to store quantified non-financial information may see accountants working more closely with other decision-making bodies.

We agree that blockchain may change the overall accounting environment in the future. With increased disclosure and traceability, accountants and other stakeholders will have access to data from all agents belonging to the same ecosystem. Companies will not only focus only on their actions and transactions but will think more widely about being part of self-assuring accounting ecosystems based on blockchain (Dai and Vasarhelyi, 2017). The overall influence of blockchain on the accounting profession and accounting environment will depend on developing new paradigms that enable better understanding, interpretation and use of this data in decision-making. As Marrone and Hazelton (2019, p. 685) argue:

The disruptive potential of accounting technologies can only be fully realised with a similarly profound revolution in accounting thinking. Without an accompanying "mental revolution", new technologies may result in incremental as opposed to step change.

\subsection{New challenges for auditors}

Blockchain may also disrupt the auditing profession. With the ability to autonomously execute some audit procedures based on blockchain, smart contracts will provide stakeholders with already partly verified information (Rozario and Vasarhelyi, 2018). La Torre et al. (2018) claim that participants in the accounting ecosystem may act as auditors themselves. Accounting information may be verified by different actors thanks to the assurance abilities of blockchain and because companies can continuously share information. Moreover, there is the possibility to automate some external auditing functions over the blockchain to improve audit quality and narrow the expectation gap between auditors, financial statement users and regulatory bodies (Rozario and Vasarhelyi, 2018). Some authors call for the appearance of a new brand of auditor that can offer attestation services for independent evaluations of blockchain controls (Canelón et al., 2019; Sheldon, 2019).

However, some researchers are not convinced that blockchain will dramatically impact the auditing profession. Rather, they suggest that auditing will take on new features and become more complicated (Dai et al., 2019; Issa et al., 2016). Distributed public recording on the
Blockchain in accounting research 
AAAJ

35,7

1520

blockchain will allow real-time audits in many locations and organisations simultaneously (Issa et al., 2016). These authors argue that auditors will need improved skills to audit the data not only for one company but also for the whole accounting ecosystem.

We agree that blockchain will force auditors to increase automation, including automated analytics and continuous monitoring and that doing this will improve audit scope and efficiency (Rozario and Vasarhelyi, 2018). We expect that automatic cross-validation of a transaction will be the key component that leads auditors towards a new generation of "Audit 4.0" (Dai et al., 2019, p. 23), where they will

... continuously collect data from the real world, create a variety of intelligent modules for real-time auditing, monitoring, fraud detection, etc., and thereby improve the effectiveness and efficiency of assurance services.

Blockchain will require auditors to gain new IT skills and technical knowledge as without an improved understanding of blockchain, they will not be able "to design efficient and effective audit processes, to collect accurate audit evidence, and to review the system for potential risks and frauds" (Dai et al., 2019, p. 38). Of course, for blockchain technology to enable continuous auditing and for it to give auditors a better understanding of their clients' businesses, companies will need to record all transactions on the blockchain (Schmitz and Leoni, 2019). After all, "real-time auditing" can only be delivered to the degree that transactions are recorded on the blockchain.

In future, auditors will be asked to focus on truly complex and controversial issuescomplex non-standard operations, effective internal control mechanisms, analytics and forecasting (Kwilinski, 2019). Hence, the need for professional judgement will persist. As Tiberius and Hirth (2019, p. 10) state, "goodwill, trade names or provisions somewhat depend on individual discretionary judgement". Auditing such complicated transactions on the blockchain will require even more skills and knowledge from the auditors. At the same time, with the increased access to different types of data and information, we believe that ethical issues and moral judgement from auditors will be required more often. As La Torre et al. (2021, p. 235) argue:

Auditors should be concerned about the risks of privacy breaches deriving not only from both external unauthorised access but also from accessing and using certain corporate and external data to perform audit activities; the latter being a task that needs to engage principles that go beyond legal prohibitions.

Because the role of auditors is closely linked to "trust", the ethical dimension of auditing is another reason why we think that auditing will not disappear. As Schmitz and Leoni (2019, p. 337) note:

Blockchains do not provide a guarantee for transactions taking place in the real world. Even if they are recorded onto blockchains, transactions may still be fraudulent, illegal or unauthorised. Hence, given the need for auditors to detect and investigate transaction errors or fraud, the argument of auditors becoming obsolescent is not evident.

Essential roles for auditors in the future will be assuring the reliability, credibility and authorisation process of blockchain transactions.

Implementing blockchain may benefit most accountants and auditors, but it may be negatively perceived by those who work in the black economy, those who are keen on earnings management, and those who need to manipulate the appearance of illicit transactions. Therefore, we assume that automating data collection and storage using blockchain will not mean the auditing profession disappears. Rather, we see it evolving into a new role within companies and the ecosystem of blockchain accounting. 


\subsection{Opportunities and challenges of blockchain technology application}

Papers on this topic are mostly written from the perspective of a company implementing blockchain. Opportunities range from improved efficiency, transparency and trust to the high potential of new business models and ecosystems that evolve due to blockchain. Challenges include potential risks related to blockchain implementation, the influence of context and a high demand for energy consumption.

Because blockchain eliminates the need to enter and reconcile information in multiple databases, efficiency gains are a key strength. Blockchain also saves time by increasing the speed of transactions, reducing human error and minimising fraud (Kokina et al., 2017; O'Leary, 2017). The use of smart contracts may also improve processes in a range of industries. Smart contracts on the blockchain execute when certain conditions are met without the need for trusted intermediaries to verify the fact (Coyne and McMickle, 2017; Kokina et al., 2017). There is already evidence to show how blockchain may reduce costs in the finance industry (e.g. Fanning and Centers, 2016; Kokina et al., 2017).

One of the challenges for implementing blockchain is context (Stratopoulos and Calderon, 2018). It is unlikely that small firms would want to make their transactions publicly available or that they would benefit from blockchain accounting as much as big companies. Distributed ledgers may not be attractive or even needed by every company, so there is a real need to ascertain exactly what the up and downsides of implementing blockchain are. As O'Leary (2019) observes, the opportunities for using blockchain may be limited by the desire and ability of all agents in the ecosystem to implement it. For example, some companies may wish to use a private blockchain, but we do not yet know how to accommodate multiple private blockchains with different levels of secrecy and different kinds of trading partners, some of whom may be members of a public blockchain (O'Leary, 2019; Kim and Laskowski, 2018).

It is also important to understand all the advantages and disadvantages of joining a public or a private blockchain (O'Leary, 2017). There are many different configurations of blockchain, e.g. peer-to-peer and public, cloud-based, private and these all need to be analysed before they can be soundly implemented in different settings. Further, those investigations must include analyses at the accounting, auditing and supply chain levels. For example, O'Leary (2017) argues that public blockchains are not the best approach to capturing accounting or supply chain transactions. Instead, he believes private and cloud-based blockchain configurations will dominate the corporate landscape. In a private blockchain, only a preselected number of nodes are authorised to use the ledger. Hence, not everyone has access to all company's data. Yet many researchers speak positively about how blockchain technology will mean provenance in the supply chain that is much more traceable (Kim and Laskowski, 2018). In our opinion, it will be important for all the agents in the ecosystem to understand how blockchain provides similar benefits. For example, due to the potential risks of disclosing information, we assume that blockchain will have a more restrictive effect on business entities than non-profit organisations, because non-profits tend not to hold as many commercial secrets.

Moreover, Kokina et al. (2017) note that the scalability of blockchain is an issue from a technical perspective, as blockchain is computationally intensive and requires a lot of energy. This raises sustainability questions and may not be an issue that gets resolved until renewable energy accounts for most of our energy production (Coyne and McMickle, 2017). Three further risks are often raised, each surrounding changing business processes (Canelón et al., 2019; Coyne and McMickle, 2017; Kokina et al., 2017). The first relates to the centralisation of computing power, also called the " $51 \%$ attack risk", which can happen when most of the computing power in a blockchain's network is centralised. In this case, whoever controls that power can, with impunity, discard a valid link in the chain or substitute an invalid block for a valid one. The second risk is transaction malleability, which occurs when
Blockchain in accounting research 
AAAJ 35,7

an attacker copies a transaction and modifies it to receive tokens (payment) then claims that no tokens were ever received. The third risk relates to flawed smart contracts that can hide malicious code or another contract with a weakness. This risk highlights the need for independent external auditors to approve transactions before the contract enters the blockchain. In short, the ability of blockchain to store records makes it a target for potential cyberattacks. Therefore, to ensure the security of information in a blockchain, there is a need to implement internal and cybersecurity controls that consider privacy preservation issues (Chohan, 2017; Coyne and McMickle, 2017; O’Leary, 2017).

Considering the advantages and challenges blockchain technology faces, we think its implementation will take time. Implementing blockchain is not merely about automating business processes; it is also about changing them. As O'Leary (2017, p. 145) states:

To gain real efficiencies in the use of blockchain or any technology, there is a need to reengineer, rather than just automate, existing processes. Unfortunately, many of the proposals for the use of blockchain are aimed at automating existing processes, typically in an approach to leverage the immutability and digitisation of paper, but generally do not propose or use changes in the processes.

Unless existing processes and systems are truly scrutinised for their potential to benefit from blockchain technology, the full range of opportunities that blockchain presents will not be realised. Blockchain will only become a "game-changer" if all parties involved in the accounting ecosystem are open to its potential.

\subsection{Regulation of cryptoassets}

The papers devoted to this topic analyse a variety of questions related to the regulation of cryptoassets (also called tokens), including cryptocurrencies and ICOs (e.g. Gurrea-Martínez and Remolina, 2018; Wiśniewska, 2018). These assets are not addressed by any accounting standards, that leads to challenges in their classification and measurement and reflects the lack of economic characteristics for a "standard" intangible asset (Procházka, 2018) or a financial asset (Smith et al., 2019). There are several regulatory issues that need to be solved: classification of cryptoassets in accounting; the kinds of insolvency that affect buyers and sellers of tokens; and the regulation of potential money laundering via blockchain (Pimentel et al., 2019; Zhang et al., 2021). Moreover, with the increased competitiveness of the market, questions related to data protection and data safety on the blockchain become extremely important for further regulation (Cai, 2018).

The uncertainty linked to valuing cryptoassets is affecting the development of proper regulations, as this issue affects the fundamental qualitative aspects of financial accounting, such as relevance and faithful representation. Moreover, as highlighted in the Conceptual Framework for Financial Reporting, the principles of prudence, neutrality and conservatism continue to pose challenges for properly presenting cryptoassets in financial statements (FRC, 2018; The Interpretations Committee, 2019).

There is no commonly shared point of view among researchers on the best way to regulate cryptoassets. Some say that they fit in with the existing accounting standards, while others state there is a need to develop a new regulatory framework that will decrease the probability of fraud (Auer, 2019; Pimentel et al., 2019). For example, there is a high demand for developing regulations for ICOs, cryptoassets that do not offer investors concrete products or services but provide an opportunity for capital gains from reselling cryptocurrencies in the future (Zhang et al., 2021). In December 2017, SEC Chairman Jay Clayton stated that ICOs are vulnerable to fraud and manipulation because there is less investor protection than in the stock market (Clayton, 2017). We think that as the tokenisation of securities would be a useful tool in capital markets in the future (as already reflected by their fast development in Asian markets) and because ICOs and crowdsourced platforms represent a legitimate means of exchange in ecosystems, the regulatory issues need to be resolved to make this instrument 
available to wider markets participants (Gurrea-Martínez and Remolina, 2018; Zhang et al., 2021; Sixt and Himmer, 2019).

Currently, regulators monitor the field of cryptoassets on a case-by-case basis, but not to the extent that investors, or would-be-investors, could determine with certainty how cryptoassets may be treated (Smith et al., 2019). Nor are all market participants eager to treat cryptoassets as a security due to their volatility, making it difficult to ascertain an appropriate value to record for income statement and balance sheet purposes (Smith et al., 2019; Tan and Low, 2019). Finally, it is worth noting that financial accounting is characterised by accounting prudence and conservatism, which can lead to differences between a company's market and book value (Dumay and Guthrie, 2019). As cryptoassets are often characterised as a potential future economic benefit, their acquisition may lead to even greater discrepancies between the market and book values of companies, especially in markets with optimistic valuations of intangible assets.

Thus, the uncertainty on measuring cryptoassets leads to the problems of comparability, verifiability, timeliness and understandability in financial accounting (IASB, 2018, p. 6). Therefore, in line with Smith et al. (2019, p. 166), we conclude that for now, "this innovative technology has the potential to change internal management systems ...; however, lack of regulation and information makes investment planning for cryptoassets complex and forbidding". The divergence of crypto classifications means that worldwide regulation and availability of information on cryptoassets will be the most important factors for their spread. As a result, we see the need for a proactive regulatory framework rather than merely reacting to questions regarding the regulation and accountability of cryptoassets.

\section{Future research directions}

This section answers RQ3: What are the future research trends related to blockchain in accounting?

The following views regarding the future research trends were framed by the insights in the previous section and reviewing the most representative papers for each topic.

\subsection{The changing role of accountants}

As discussed in Section 5.1, most papers on the changing role of accountants are normative. They talk mainly about various assumptions over how blockchain may influence accounting. One of the main changes frequently discussed is how blockchain will change the way accountants collect information. Given this, we think the future will result in more case studies and practically-oriented papers that empirically test blockchain's impact on accounting (Alles, 2018). According to Zhang et al. (2017), new business reporting models, such as triple-entry accounting, will demand investigations into how blockchain strengthens or alters functions like valuations and contracting. Further, the monitoring role of accountants in managing information for the benefit of stakeholders will need to be established (Zhang et al., 2017). However, Alles (2018) warns that there is a danger of the "empirical takeover" effect when papers become empirically driven. Thus, there is a need to establish a solid theoretical and conceptual background for how blockchain will disrupt accountancy.

The role of management in implementing blockchain is very important. According to Jarvenpaa and Ives (1991, p. 205), "Few nostrums have been prescribed so religiously and ignored as regularly as top management support in the development and implementation of IT.” A high degree of support for specific IT innovations is needed to ensure companies hold fast to a long-term vision and optimally manage their resources to see it through. At the same time, these innovations can create a favourable organisational climate that can overcome
Blockchain in accounting research 
AAAJ 35,7

1524

barriers and resistance to change (Clohessy and Acton, 2019). Future research might therefore investigate the structure of management bodies and the role of top management in blockchain implementation.

Prior research points to a growing trend in the topic of new skills for teams when implementing blockchain and using this technology in day-to-day work (Changati and Kansal, 2019). Fang and Hope (2021) indicate that blockchain is more effectively implemented in teams comprising accountants, managers and experienced analysts as opposed to teams consisting only of highly experienced analysts. We expect that blockchain will involve more multi-tasked teams with diverse knowledge and skills to generate additional synergies. Therefore, future research may analyse the characteristics of teams and government bodies that work better together for the most efficient implementation and decision-making using blockchain.

\subsection{New challenges for auditors}

In the realm of auditing, future research could explore how different types of blockchain (public, private and permissioned) could be used in accounting and Audit 4.0 to improve the quality of the data collected (Dai et al., 2019). The dilemma of adopting blockchain in accounting and auditing is in finding the right trade-off between information confidentiality and transparency. The simultaneous protection of data privacy and maintenance of data accuracy is an important area for future research. Further, the ways of creating effective smart audit contracts and smart reporting contracts should also be studied with a special focus on executing traces and enforceability (Schmitz and Leoni, 2019).

More extensive analysis is also needed on the auditing ecosystems based on blockchain (Smith, 2020). For example, if a client is a part of several blockchains, any engagement to audit or attest that information must include an examination of all associated blockchains. In the case of supply chains, cross-border payments, and transfers of intellectual capital, the chains-be they digital or physical in nature-can include dozens, if not hundreds, of organisations. How to conduct an effective and successful audit of such systems should attract the attention of researchers.

Additionally, more real cases will need to be explored to see how technology might disrupt the auditing community (Marrone and Hazelton, 2019). Researchers might also address data protection issues as well as the new skills and competencies needed to remain relevant and add value (Moll and Yigitbasioglu, 2019). Some, like Siew et al. (2020), argue that, while digitising the validation process will reduce errors, and the immutability of the blockchain will minimise the opportunity to commit fraud, blockchain accounting does not guarantee that financial reports will be true and fair; the processes still need to be tested and the various accounting judgements still need to be reviewed. Moreover, blockchain will not resolve questions over issues like reconciling accounting standards. Hence, accountants will still need to be involved in the process (Cai, 2018). Thus, many of the benefits and challenges of blockchain for auditing still need to be analysed.

\subsection{Opportunities and challenges of blockchain technology application}

A more fundamental area of future research is the role of financial intermediaries and how their role might change. In the future, we expect to see competition and cooperation among traditional and new intermediaries, and research needs to explore these phenomena to provide guidance to all participants such as incumbents, new entries and regulators (Cai, 2018). The influence of blockchain on risk management and companies' performance indicators is another promising area for future research as there is a need to identify how stakeholders' value creation may be affected by implementing blockchain (Cai, 2018). It would also be worth examining whether the response of managers towards blockchain varies in different industries (Cao et al., 2018). Burragoni (2017) argues that implementing blockchain in the finance industry 
might help overcome the threat of a shadow economy, given the improved transparency and legitimacy on offer, but this is an assumption that needs further justification.

Analysing the role of blockchain in changing business models in different industries is sure to be a topic of great interest to researchers (Johannessen, 2013). The efficiency of new business models in comparison to traditional ones may also bring new insights for academics and practitioners. Researchers should test new business models in a market and evaluate transaction efficiency and the degree of novelty in the transaction's content, structure, steering, resource use, network effects and value creation for stakeholders. Researchers can analyse the efficiency of blockchain implementation in different areas and focus on "the benefits of the first-mover advantage" (Karajovic et al., 2019, p. 322). In the future, it will be important to monitor the progress of the implementation of blockchain in different types of organisations (Gietzmann and Grossetti, 2019).

Researchers should analyse how blockchain ecosystems evolve and are applied (Benjaafar et al., 2018). Blockchain enables real-time, verifiable and transparent accounting, making it reasonable to assume that accounting information systems will become ecosystems. In a data ecosystem that progressively integrates a nearly infinite set of initially disconnected data, the ability to integrate coherently and apply software agents will be of high importance. With an almost infinite supply of new data, novel methods of measuring business performance will inevitably emerge (Cho et al., 2019). Understanding how blockchain distributes the power of transaction verification and how data are stored and managed to prevent any unauthorised data changes in ecosystems are also key questions in need of investigation.

The challenges of blockchain regarding sustainability and environmental issues should also be a focus in future research. On the one hand, a distributed carbon ledger system based on blockchain technology will not only strengthen the corporate accounting system for carbon asset management but also will fit within existing market-based emissions trading schemes (Tang and Tang, 2019). Blockchain will help integrate national emission trading schemes and corporate carbon asset management into a single synthesised mechanism, making it possible to analyse the overall efficiency of carbon trading markets in some great amount of detail. On the other hand, Nyumbayire (2017) points to environmental sustainability as an issue, explaining that the algorithms that run blockchain require a great deal of electricity. Moreover, as the technology grows, the algorithms become more complicated, and more time and energy are required to validate transactions. We argue that in the future, researchers should investigate the sustainability and environmental issues related to blockchain in more detail.

\subsection{Regulation of cryptoassets}

To date, the growth of blockchain technology has not led to the building of a corresponding regulatory framework. Thus, there are many questions that need to be resolved surrounding the legal and accounting frameworks for accounting, recognising and valuing cryptoassets. Further, when these frameworks are developed, they will need to be analysed. Researchers will also likely want to determine whether the standard-setting bodies have developed credible reporting conventions over the financial implications of cryptocurrency transactions (Raiborn and Sivitanides, 2015; Tan and Low, 2019). Future research could explore whether blockchain has or will have a positive effect on the timeliness of disclosures; how financial reporting standards welcome new types of assets; and how the uncertainty associated with cryptoassets can be overcome.

Academics, together with practitioners, should work on specifying how these regulatory dimensions need to be developed, what type of disclosures are relevant to cryptocurrencies and how disclosure costs may further impact market uncertainty (Cao et al., 2018). Clarifying the regulatory framework will probably also lead to more ICOs, as initiators will be better prepared and be able to respond to uncertainty in blockchain policy by increasing their
Blockchain in accounting research 
AAAJ 35,7

1526 voluntary disclosures (Zhang et al., 2021; Gurrea-Martínez and Remolina, 2018). Research on the efficiency and effectiveness of ICOs will be of high interest in the future.

How cryptoassets and cryptocurrencies should be taxed is also open to question (Ram, 2018). Once clarified, researchers will be able to study the taxation policies applicable to this new class of assets in detail. One related research question for the future involves whether blockchainbased instant tax allocation helps to decrease the cost of tax compliance for companies or not (Karajovic et al., 2019). As the role of external contexts and legal frameworks is highly important to blockchain development (Allen et al., 2020; Stratopoulos and Calderon, 2018), researchers may study the differences in blockchain implementation in environments that are (and are not) "crypto-friendly".

\section{Conclusion}

Our aim with this paper was to define the key topics and trends, past, present and future, that concern researchers in blockchain for accounting. Our analysis systematically identified these topics by analysing 153 relevant papers. By combining machine-learning methods with more traditional approaches, we were able to draw a holistic picture of the critical advances and trends in the corpus of literature. The results indicate that the most widely discussed topics are the changing role of accountants, new challenges for auditors, the opportunities and challenges of blockchain technology application, and the regulation of cryptoassets.

This paper provides a compact snapshot of the state of blockchain papers in accounting research. The trends and identified research directions may help predict future citation impact and informed our suggestions for future research. They may also help journal editors decide on calls for special issues as interest in this topic grows.

\subsection{Implications for academics}

Our analysis reveals that more than two-thirds of the papers under review were published in journals, while less than a third represent works in progress uploaded to SSRN. The top accounting journals from the ABS and ABDC rankings appear to be resistant to the blockchain field of research, as they have published only a few papers devoted to the technology. This could be because those journals are less friendly towards phenomenon-based research (Von Krogh et al., 2012) than fundamental research or that the publication process takes much longer, and we will see more papers in the upcoming years. Another reason could be that most existing articles are normative and are looking at the future applications of blockchain. We may assume that, in the future, when there will be more cases examining the actual application of blockchain in accounting practices and real examples of the influence of blockchain on the accounting and auditing field, the number of papers in the leading journals may increase. For now, we observe that, with the blockchain landscape changing daily, and ideas and research needing to reach the target audience faster than the traditional journal route allows, researchers are turning to SSRN to share their tentative findings (Holub and Johnson, 2017). We also observe that Australian scholarship is now leading the blockchain research in accounting, as more papers were published in journals included in the ABDC ranking compared to the ABS ranking. Moreover, Australian journals such as the Australian Accounting Review and Meditari Accounting Research are among the top tiers of those who welcome such research.

It will be important to monitor the progress in the take-up of blockchain in the future (Bonsón et al., 2019; Gietzmann and Grossetti, 2019; Bonsón and Bednárová, 2019). More papers applying machine learning techniques will help to gather information from reports, and web crawlers will be able to discover new aspects of how blockchain technologies have been implemented in practice. Combined with manual analysis, these data will help to chart new paths forward for researchers. 


\subsection{Implications for accounting practice}

Even though we anticipate that blockchain will influence accounting and auditing, we do not assume they will be totally replaced. Most expect that these professions will be augmented rather than fully automated, and the need for accountants and auditors will not disappear (Agnew, 2016; Marrone and Hazelton, 2019). There will still be a need for professional judgement, and, further, issues such as reconciliation are almost impossible to perform at the current stage of blockchain's development. In line with McGuigan and Ghio (2019), we argue that accountants will not only have to understand the data on blockchain, they will also have to interpret and explain the implications of this information to management and other decision-makers. As a result, accountancy is likely to become a much more strategically oriented profession.

However, the skills required of accountants are likely to change, and there may be a need for fewer entry-level accountants (Kokina and Davenport, 2017; Marrone and Hazelton, 2019). There may be a shift towards notions such as creativity, innovation, holistic thinking, complex decision-making and sense-making. The ability to adapt to keep pace with an increasingly evolving business environment and technological context will also be important. Addressing such changes in education through content and delivery is necessary to ensure that graduates have up-to-date and workplace-relevant knowledge and can keep up with global accreditation standards and professional qualifications (Al-Htaybat et al., 2018). Teams, management and government bodies implementing blockchain and making decisions based on data obtained from blockchain will also need new skills to adapt to the changing environment (Pimentel et al., 2019; Siew et al., 2020). Therefore, we propose that universities and higher education institutions should change and improve the curriculum of accounting and finance programmes to help students develop the above-mentioned skills. It is essential to start making the changes now as current students will soon become accounting and auditing practitioners as well as managers working with blockchain and other disruptive technologies.

\subsection{Implications for policy}

The literature review reveals a pressing need for legal frameworks to govern blockchain technologies and regulate cryptoassets. Comprehensive work by regulators and policymakers may help implement and spread these technological innovations further, opening new sources of financing for companies. There is also a need to work on legal and taxation policies for tokens, bitcoins and other cryptocurrencies so that they become valuable tools and stable assets in capital markets. With the improved regulatory framework, we also propose that in the future governments may develop national cryptocurrencies, e.g. cryptoeuros or crypto dollars, that will be easier and faster to use compared to existing currencies. A well-developed regulatory framework may help tokens become a legitimate means of exchange in ecosystems that will start growing in the future. Further work is required from accounting bodies to accept new types of digital assets and develop standards that will solve the issues related to their recognition, measurement and disclosure. In the future, the implementation of blockchain may also raise questions related to the regulation of social and environmental accounting that becomes possible with this technology. All this will help to improve transparency further and decrease information asymmetry in the market.

\subsection{Limitations}

This study has several limitations. First, the sample only covers the period till June 2020. Extending this timeline could be an option for future research. Second, other machine learning techniques could be applied while working with the corpus of literature. Although our LDA approach is much more advanced than mere word count or word cloud methods, it still models documents using a bag-of-words representation. A similar topic model using more advanced neural natural language processing (NLP) architectures like Bidirectional
Blockchain in accounting research 
AAAJ 35,7

Encoder Representations from Transformers (BERT) (Devlin et al., 2018) or Generative Pretrained Transformer 3 (GPT-3) (Brown et al., 2020) that also consider the context and semantics of words might result in different fields of inquiry or a more revealing combination of topics. Third, we included articles uploaded to the SSRN database as well as published articles in ranked journals. We are aware that the peer-review process is accepted as a proxy for the quality of published works, especially with respect to academic journal articles (Hart, 1999; Massaro et al., 2015). However, we believe that, given the speed of new knowledge development, especially in the areas of disruptive technologies like blockchain, papers from SSRN added an important contribution to the topics identified. Finally, the validity of the results can only be considered at the time of the analysis, as literature reviews "are not a panacea" (Massaro et al., 2015, p. 546). They only identify the current state of the field, and they only offer pathways for future research directions at a particular point in time.

\section{References}

Agnew, H. (2016), “Auditing: pitch battle”, retrieved 20 June 2019, available at: www.ft.com/content/ 268637f6-15c8-11e6-9d98-00386a18e39d (accessed 30 January 2021).

Al-Htaybat, K., von Alberti-Alhtaybat, L. and Alhatabat, Z. (2018), "Educating digital natives for the future: accounting educators' evaluation of the accounting curriculum”, Accounting Education, Vol. 27 No. 4, pp. 333-357.

Allen, D.W., Berg, C., Markey-Towler, B., Novak, M. and Potts, J. (2020), "Blockchain and the evolution of institutional technologies: implications for innovation policy", Research Policy, Vol. 49 No. 1, p. 103865.

Alles, M. (2018), "Examining the role of the AIS research literature using the natural experiment of the 2018 JIS conference on cloud computing", International Journal of Accounting Information Systems, Vol. 31, pp. 58-74.

Alvesson, M. and Deetz, S. (2000), Doing Critical Management Research, Sage, London.

Asmussen, C.B. and Møller, C. (2019), "Smart literature review: a practical topic modelling approach to exploratory literature review", Journal of Big Data, Vol. 6 No. 1, pp. 1-18.

Auer, R. (2019), "Embedded supervision: how to build regulation into blockchain finance", available at: https://ssrn.com/abstract $=3463885$ (accessed 30 June 2020).

Benjaafar, S., Chen, X., Taneri, N. and Wan, G. (2018), "A permissioned blockchain business model for green sourcing”, available at: https://ssrn.com/abstract=3305792 (accessed 30 June 2020).

Bentley, J.W., Christensen, T.E., Gee, K.H. and Whipple, B.C. (2018), "Disentangling managers' and analysts' non-GAAP reporting”, Journal of Accounting Research, Vol. 56 No. 4, pp. 1039-1081.

Black, D.E., Black, E.L., Christensen, T.E. and Gee, K.H. (2020), "Comparing non-GAAP EPS in earnings announcements and proxy statements", available at: https://ssrn.com/ abstract $=2343140$ (accessed November 2020).

Blei, D.M., Ng, A.Y. and Jordan, M.I. (2003), "Latent dirichlet allocation”, Journal of Machine Learning Research, Vol. 3 Nos 4-5, pp. 993-1022.

Bonsón, E. and Bednárová, M. (2019), "Blockchain and its implications for accounting and auditing", Meditari Accountancy Research, Vol. 27 No. 5, pp. 725-740.

Bonsón, E., Perea, D. and Bednárová, M. (2019), "Twitter as a tool for citizen engagement: an empirical study of the Andalusian municipalities", Government Information Quarterly, Vol. 36 No. 3, pp. 480-489.

Brown, T.B., Mann, B., Ryder, N., Subbiah, M., Kaplan, J., Dhariwal, P. and Amodei, D. (2020), "Language models are few-shot learners", available at: https://arxiv.org/pdf/2005.14165.pdf? ref=hackernoon.com (accessed 25 May 2021). 
Burragoni, V. (2017), "Financial innovations: a deeper literature review with focus on India", available at: https://ssrn.com/abstract $=2894973$ (accessed 30 June 2020).

Cai, C.W. (2018), "Disruption of financial intermediation by FinTech: a review on crowdfunding and blockchain", Accounting and Finance, Vol. 58 No. 4, pp. 965-992.

Cai, C.W., Linnenluecke, M.K., Marrone, M. and Singh, A.K. (2019), "Machine learning and expert judgement: analysing emerging topics in accounting and finance research in the Asia-Pacific", Abacus, Vol. 55 No. 4, pp. 709-733.

Canelón, J., Huerta, E., Incera, J. and Ryan, T. (2019), “A cybersecurity control framework for blockchain ecosystems”, The International Journal of Digital Accounting Research, Vol. 19, pp. 103-144.

Cao, S.S., Ma, G., Tucker, J.W. and Wan, C. (2018), "Technological peer pressure and product disclosure", The Accounting Review, Vol. 93 No. 6, pp. 95-126.

Casey, M.J. and Vigna, P. (2018), "In blockchain we trust", MIT Technology Review, Vol. 121 No. 3, pp. 10-16.

Changati, V. and Kansal, P. (2019), "Factors influencing technology acceptance in the banking sector: a binary recursive partitioning approach", Journal of Commerce and Accounting Research, Vol. 8 No. 1 , pp. $68-82$.

Cho, S., Vasarhelyi, M.A. and Zhang, C. (2019), "The forthcoming data ecosystem for business measurement and assurance", Journal of Emerging Technologies in Accounting, Vol. 16 No. 2, pp. 1-21.

Chohan, U.W. (2017), "The double spending problem and cryptocurrencies", available at: https://ssrn. com/abstract $=3090174$ (accessed 30 June 2020).

Clayton, J. (2017), "Statement on cryptocurrencies and initial coin offerings", available at: https://www. sec.gov/news/public-statement/statement-clayton-2017-12-11 (accessed 10 May 2021).

Clohessy, T. and Acton, T. (2019), "Investigating the influence of organisational factors on blockchain adoption: an innovation theory perspective", Industrial Management and Data Systems, Vol. 119 No. 7, pp. 1457-1491.

Conoscenti, M., Vetro, A. and De Martin, J.C. (2016), "Blockchain for the Internet of Things: a systematic literature review", 2016 IEEE/ACS 13th International Conference of Computer Systems and Applications (AICCSA), pp. 1-6, available at: http://www.antoniovetro.it/ authorsversion/conferences/2016-iotsms-bk.pdf (accessed 15 May 2020).

Coyne, J.G. and McMickle, P.L. (2017), "Can blockchains serve an accounting purpose?", Journal of Emerging Technologies in Accounting, Vol. 14 No. 2, pp. 101-111.

Cozzens, S., Gatchair, S., Kang, J., Kim, K.S., Lee, H.J., Ordóñez, G. and Porter, A. (2010), "Emerging technologies: quantitative identification and measurement", Technology Analysis and Strategic Management, Vol. 22 No. 3, pp. 361-376.

Dai, J. and Vasarhelyi, M.A. (2017), “Toward blockchain-based accounting and assurance”, Journal of Information Systems, Vol. 31 No. 3, pp. 5-21.

Dai, J., Wang, Y. and Vasarhelyi, M. (2017), "Why blockchain has the potential to serve as a secure accounting information system", The CPA Journal, Vol. 2, available at: www.cpajournal.com/ 2017/09/20/blockchain-potential-serve-secureaccounting-information-system-cpe-season/ (accessed 3 May 2021).

Dai, J., He, N. and Yu, H. (2019), "Utilising blockchain and smart contracts to enable Audit 4.0: from the perspective of accountability audit of air pollution control in China", Journal of Emerging Technologies in Accounting, Vol. 16 No. 2, pp. 23-41.

Deloitte (2016), "Blockchain technology: a game-changer in accounting?", available at: https://www2. deloitte.com/content/dam/Deloitte/de/Documents/Innovation/Blockchain_A\%20game-changer \%20in\%20accounting.pdf (accessed 3 July 2020).

Deloitte (2019), "Deloitte global blockchain survey", available at: https://www2.deloitte.com/content/ dam/Deloitte/se/Documents/risk/DI_2019-global-blockchain-survey.pdf (accessed 3 July 2020).
Blockchain in accounting research 
AAAJ 35,7

Devlin, J., Chang, M.W., Lee, K. and Toutanova, K. (2018), "Bert: pre-training of deep bidirectional transformers for language understanding", available at: https://arxiv.org/pdf/1810.04805. pdf\&usg=ALkJrhhzxlCL6yTht2BRmH9atgvKFxHsxQ (accessed 25 May 2021).

Dumay, J. and Cai, L. (2014), "A review and critique of content analysis as a methodology for inquiring into IC disclosure”, Journal of Intellectual Capital, Vol. 15 No. 2, pp. 264-290.

Dumay, J. and Guthrie, J. (2019), "Reflections on interdisciplinary critical intellectual capital accounting research", Accounting, Auditing \& Accountability Journal, Vol. 32 No. 8, pp. 2282-2306.

Dumay, J., de Villiers, C., Guthrie, J. and Hsiao, P.C. (2018), "Thirty years of Accounting, Auditing and Accountability Journal: a critical study of the journal's most cited articles", Accounting, Auditing and Accountability Journal, Vol. 31 No. 5, pp. 1510-1541.

El-Haj, M., Rayson, P., Walker, M., Young, S. and Simaki, V. (2019), "In search of meaning: lessons, resources and next steps for computational analysis of financial discourse", Journal of Business Finance and Accounting, Vol. 46 Nos 3-4, pp. 265-306.

Faccia, A. and Mosteanu, N.R. (2019), "Accounting and blockchain technology: from double-entry to triple-entry", The Business and Management Review, Vol. 10 No. 2, pp. 108-116.

Fang, B. and Hope, O.K. (2021), “Analyst teams”, Review of Accounting Studies, Vol. 26, pp. 425-467.

Fanning, K. and Centers, D.P. (2016), "Blockchain and its coming impact on financial services", Journal of Corporate Accounting and Finance, Vol. 27 No. 5, pp. 53-57.

Fligstein, N., Stuart Brundage, J. and Schultz, M. (2017), "Seeing like the Fed: culture, cognition, and framing in the failure to anticipate the financial crisis of 2008", American Sociological Review, Vol. 82 No. 5, pp. 879-909.

Financial Reporting Council (FRC) (2018), "FRC submission to the treasury select committee digital currencies inquiry", available at: https://www.frc.org.uk/getattachment/52cdb6cb-7498-4a929e67-c1f4f8fbb3f7/130418-FRC-response-Treasury-Select-Committee-Digital-Currencies-Inquiry. pdf (access 17 May 2021).

Fullana, O. and Ruiz, J. (2021), "Accounting information systems in the blockchain era”, International Journal of Intellectual Property Management, Vol. 11 No. 1, pp. 63-80.

Gietzmann, M.B. and Grossetti, F. (2019), "Blockchain and other distributed ledger technologies: where is the accounting?", available at: https://ssrn.com/abstract=3507602 (accessed 30 June 2020).

Gordon, G. (2016), "SSRN - the leading social science and humanities repository and online community-joins Elsevier", available at: https://www.elsevier.com/connect/ssrn-the-leadingsocial-science-and-humanities-repository-and-online-community-joins-elsevier (accessed 15 April 2020).

Gurrea-Martínez, A. and Remolina, N. (2018), "The law and finance of initial coin offerings", available at: https://ssrn.com/abstract $=3182261$ (accessed 30 June 2020).

Gurtu, A. and Johny, J. (2019), "Potential of blockchain technology in supply chain management: a literature review", International Journal of Physical Distribution and Logistics Management, Vol. 49 No. 9, pp. 881-900.

Hart, C. (1999), Doing Literature Review, Sage Publications, London, p. 230.

Holub, M. and Johnson, J. (2017), "Mapping bitcoin's influence on academic research", available at: https://ssrn.com/abstract=3094492 (accessed 30 June 2020).

Iansiti, M. and Lakhani, K.R. (2017), "The truth about blockchain”, Harvard Business Review, Vol. 95 No. 1, pp. 3-11.

IASB (2018), IFRS® Conceptual Framework Project Summary, International Accounting Standards Board, London.

Issa, H., Sun, T. and Vasarhelyi, M.A. (2016), "Research ideas for artificial intelligence in auditing: the formalisation of audit and workforce supplementation", Journal of Emerging Technologies in Accounting, Vol. 13 No. 2, pp. 1-20. 
Jarvenpaa, S.L. and Ives, B. (1991), "Executive involvement and participation in the management of information technology", MIS Quarterly, June, pp. 205-227.

Johannessen, J.A. (2013), "Innovation: a systemic perspective-developing a systemic innovation theory", Kybernetes, Vol. 42 No. 8, pp. 1195-1217.

Jones, S. and Alam, N. (2019), "A machine learning analysis of citation impact among selected Pacific Basin journals", Accounting and Finance, Vol. 59 No. 4, pp. 2509-2552.

Karajovic, M., Kim, H.M. and Laskowski, M. (2019), "Thinking outside the block: projected phases of blockchain integration in the accounting industry", Australian Accounting Review, Vol. 29 No. 2, pp. 319-330.

Kim, H.M. and Laskowski, M. (2018), "Toward an ontology-driven blockchain design for supply-chain provenance", Intelligent Systems in Accounting, Finance and Management, Vol. 25 No. 1, pp. 18-27.

Kokina, J. and Davenport, T.H. (2017), "The emergence of artificial intelligence: how automation is changing auditing”, Journal of Emerging Technologies in Accounting, Vol. 14 No. 1, pp. 115-122.

Kokina, J., Mancha, R. and Pachamanova, D. (2017), "Blockchain: emergent industry adoption and implications for accounting", Journal of Emerging Technologies in Accounting, Vol. 14 No. 2, pp. 91-100.

Kwilinski, A. (2019), "Implementation of blockchain technology in accounting sphere", Academy of Accounting and Financial Studies Journal, Vol. 23, pp. 1-6.

La Torre, M., Sabelfeld, S., Blomkvist, M., Tarquinio, L. and Dumay, J. (2018), "Harmonising nonfinancial reporting regulation in Europe", Meditari Accountancy Research, Vol. 26 No. 4, pp. 598-621.

La Torre, M., Botes, V.L., Dumay, J. and Odendaal, E. (2021), "Protecting a new Achilles heel: the role of auditors within the practice of data protection", Managerial Auditing Journal, Published Online, Vol. 36 No. 2, pp. 218-239.

Lev, B. and Gu, F. (2016), The End of Accounting and the Path Forward for Investors and Managers, John Wiley and Sons, Hoboken, New Jersey, NJ.

Li, F. (2010), "Textual analysis of corporate disclosures: a survey of the literature", Journal of Accounting Literature, Vol. 29, pp. 143-165.

Linnenluecke, M.K., Marrone, M. and Singh, A.K. (2020), "Conducting systematic literature reviews and bibliometric analyses", Australian Journal of Management, Vol. 45 No. 2, pp. 175-194.

Marrone, M. and Hazelton, J. (2019), "The disruptive and transformative potential of new technologies for accounting, accountants and accountability”, Meditari Accountancy Research, Vol. 27 No. 5, pp. 677-694.

Massaro, M., Dumay, J. and Garlatti, A. (2015), "Public sector knowledge management: a structured literature review", Journal of Knowledge Management, Vol. 19 No. 3, pp. 530-558.

Massaro, M., Dumay, J. and Guthrie, J. (2016), "On the shoulders of giants: undertaking a structured literature review in accounting", Accounting, Auditing \& Accountability Journal, Vol. 29 No. 5, pp. 767-801.

McGuigan, N. and Ghio, A. (2019), "Art, accounting and technology: unravelling the paradoxical inbetween", Meditari Accountancy Research, Vol. 27 No. 5, pp. 789-804.

Moll, J. and Yigitbasioglu, O. (2019), "The role of internet-related technologies in shaping the work of accountants: new directions for accounting research", The British Accounting Review, Vol. 51 No. 6, p. 100833.

Moro, S., Cortez, P. and Rita, P. (2015), "Business intelligence in banking: a literature analysis from 2002 to 2013 using text mining and latent Dirichlet allocation”, Expert Systems with Applications, Vol. 42 No. 3, pp. 1314-1324.

Nakamoto, S. (2008), "Bitcoin: a peer-to-peer electronic cash system", available at: https://bitcoin.org/ bitcoin.pdf (accessed 20 June 2020). 
AAAJ 35,7

Nyumbayire, C. (2017), "Blockchain technology innovations part 1", available at: www.interlogica.it/ en/insight/blockchain-technology-innovations-part-i/ (accessed 1 August 2021).

O'Leary, D.E. (2017), "Configuring blockchain architectures for transaction information in blockchain consortiums: the case of accounting and supply chain systems", Intelligent Systems in Accounting, Finance and Management, Vol. 24 No. 4, pp. 138-147.

O'Leary, D.E. (2019), "Some issues in blockchain for accounting and the supply chain, with an application of distributed databases to virtual organisations", Intelligent Systems in Accounting, Finance and Management, Vol. 26 No. 3, pp. 137-149.

Panetta, K. (2018), "Why blockchain matters to supply chain executives”, available at: https://www.gartner. com/smarterwithgartner/why-blockchain-matters-to-supply-chain-executives/ (accessed 15 May 2020).

Pimentel, E., Boulianne, E., Eskandari, S. and Clark, J. (2019), "Systemising the challenges of auditing blockchain-based assets”, available at: https://ssrn.com/abstract=3359985 (accessed 30 June 2020).

Procházka, D. (2018), "Accounting for bitcoin and other cryptocurrencies under IFRS: a comparison and assessment of competing models", The International Journal of Digital Accounting Research, Vol. 18 No. 24, pp. 161-188.

Rabbani, M.R., Khan, S. and Thalassinos, E.I. (2020), "FinTech, blockchain and Islamic finance: an extensive literature review", International Journal of Economics and Business Administration, Vol. 8 No. 2, pp. $65-86$.

Raiborn, C. and Sivitanides, M. (2015), "Accounting issues related to bitcoins", Journal of Corporate Accounting and Finance, Vol. 26 No. 2, pp. 25-34.

Ram, A.J. (2018), "Taxation of the bitcoin: initial insights through a correspondence analysis", Meditari Accountancy Research, Vol. 26 No. 2, pp. 214-240.

Röder, M.,Both, A. and Hinneburg, A. (2015), “Exploring the space of topic coherence measures”, Proceedings of the Eighth ACM International Conference on Web Search and Data Mining, pp. 399-408.

Rozario, A.M. and Vasarhelyi, M.A. (2018), "Auditing with smart contracts”, International Journal of Digital Accounting Research, Vol. 18, pp. 1-27.

Schmitz, J. and Leoni, G. (2019), "Accounting and auditing at the time of blockchain technology: a research agenda”, Australian Accounting Review, Vol. 29 No. 2, pp. 331-342.

Sheldon, M.D. (2019), "A primer for information technology general control considerations on a private and permissioned blockchain audit", Current Issues in Auditing, Vol. 13 No. 1, pp. 15-29.

Shen, C. and Pena-Mora, F. (2018), "Blockchain for cities - a systematic literature review", available at: https:/ieeexplore.ieee.org/stamp/stamp.jsp?arnumber $=8531608$ (accessed 20 May 2020).

Siew, E.G., Rosli, K. and Yeow, P.H. (2020), "Organisational and environmental influences in the adoption of computer-assisted audit tools and techniques (CAATTs) by audit firms in Malaysia”, International Journal of Accounting Information Systems, Vol. 36, March, 100445.

Sixt, E. and Himmer, K. (2019), "Accounting and taxation of cryptoassets”, available at: https://ssrn. com/abstract $=3419691$ (accessed 30 June 2020).

Small, H., Boyack, K.W. and Klavans, R. (2014), "Identifying emerging topics in science and technology”, Research Policy, Vol. 43 No. 8, pp. 1450-1467.

Smith, S.S. (2017), "Sustainability: how accountants can add value and deliver results", Management Accounting Quarterly, Vol. 19 No. 1, pp. 19-30.

Smith, S.S. (2020), "Blockchains impact on risk assessment procedures", Journal of Forensic and Investigative Accounting, Vol. 12 No. 1, pp. 55-65.

Smith, S.S., Petkov, R. and Lahijani, R. (2019), "Blockchain and cryptocurrencies-considerations for treatment and reporting for financial services professionals", International Journal of Digital Accounting Research, Vol. 19, pp. 59-78.

Stratopoulos, T.C. and Calderon, J. (2018), "Introduction to blockchain with R", available at: https:// ssrn.com/abstract $=3189518$ (accessed 30 June 2020). 
Tan, B.S. and Low, K.Y. (2019), "Blockchain as the database engine in the accounting system", Australian Accounting Review, Vol. 29 No. 2, pp. 312-318.

Tang, Q. and Tang, L.M. (2019), "Toward a distributed carbon ledger for carbon emissions trading and accounting for corporate carbon management", Journal of Emerging Technologies in Accounting, Vol. 16 No. 1, pp. 37-46.

The Interpretations Committee (2019), "Holdings of cryptocurrencies", available at: https://www.ifrs. org/projects/completed-projects/2019/holdings-of-cryptocurrencies/ (accessed 17 May 2021).

Tiberius, V. and Hirth, S. (2019), "Impacts of digitisation on auditing: a Delphi study for Germany", Journal of International Accounting, Auditing and Taxation, Vol. 37, p. 100288.

Uwizeyemungu, S., Bertrand, J. and Poba-Nzaou, P. (2020), "Patterns underlying required competencies for CPA professionals: a content and cluster analysis of job ads", Accounting Education, Vol. 29 No. 2, pp. 109-136.

Von Krogh, G., Rossi-Lamastra, C. and Haefliger, S. (2012), "Phenomenon-based research in management and organisation science: when is it rigorous and does it matter?", Long Range Planning, Vol. 45 No. 4, pp. 277-298.

Wang, Y. and Kogan, A. (2018), "Designing confidentiality-preserving blockchain-based transaction processing systems", International Journal of Accounting Information Systems, Vol. 30, pp. 1-18.

Wang, Y., Han, J.H. and Beynon-Davies, P. (2019), "Understanding blockchain technology for future supply chains: a systematic literature review and research agenda", Supply Chain Management: An International Journal, Vol. 24 No. 1, pp. 62-84.

Wanner, F., Stoffel, A., Jäckle, D., Kwon, B.C., Weiler, A., Keim, D.A., Isaacs, K.E., Giménez, A., Jusufi, I. and Gamblin, T. (2014), "State-of-the-art report of visual analysis for event detection in text data streams", Conference presentation at the EuroVis 2014: The Eurographics Conference on Visualization, Swansea, Wales, UK, 9-13 June.

Wiśniewska, A. (2018), "The initial coin offering-challenges and opportunities", Copernican Journal of Finance and Accounting, Vol. 7 No. 2, pp. 99-110.

Xu, M., Chen, X. and Kou, G. (2019), “A systematic review of blockchain”, Financial Innovation, Vol. 5 No. 1, pp. 1-14.

Yermack, D. (2017), "Corporate governance and blockchains", Review of Finance, Vol. 21 No. 1, pp. 7-31.

Yu, T., Lin, Z. and Tang, Q. (2018), "Blockchain: the introduction and its application in financial accounting", Journal of Corporate Accounting and Finance, Vol. 29 No. 4, pp. 37-47.

Zhang, L., Pei, D. and Vasarhelyi, M.A. (2017), "Toward a new business reporting model”, Journal of Emerging Technologies in Accounting, Vol. 14 No. 2, pp. 1-15.

Zhang, S., Zhang, D., Zheng, J. and Aerts, W. (2021), "Does policy uncertainty of the blockchain dampen ICO markets?", Accounting and Finance, Vol. 61 No. S1, pp. 1625-1637.

\section{Corresponding author}

Tatiana Garanina can be contacted at: tatiana.garanina@uwasa.fi

For instructions on how to order reprints of this article, please visit our website:

www.emeraldgrouppublishing.com/licensing/reprints.htm

Or contact us for further details: permissions@emeraldinsight.com
Blockchain in accounting research 